компьютеризации исторического образования в странах СНГ: Сб. ст. / Под ред. В.Н. Сидорцова, Е.Н. Балыкиной. - Мн.: БГУ, 1999. - С. 71-81 URL: $\quad$ https://docplayer.ru/34195292-Distancionnoe-obuchenie-istoriiproblemy-i-perspektivy-v-m-vymyatin-v-p-demkin-g-v-mozhaeva-institutdistancionnogo-obrazovaniya-tomsk-rossiya.html (дата звернення: 15.11.2020)

5. Черченко О. Світові та українські музеї в умовах інформаційнокомп'ютерного суспільства - URL: http:www. dspace.nbuv.gov.ua/.../08cherchenko.pdf?...1. (дата звернення: 15.11.2020)

6. Бєлікова М. Запровадження інноваційних технологій в музеях України. - URL: http://old.istznu.org/dc/file.php?host_id=1\&path=/ page/issues/43/66.pdf (дата звернення: 15.11.2020)

DOI https://doi.org/10.30525/978-9934-26-004-9-38

\title{
МУЗЕЙНА СПАДЩИНА УКРАЇНИ ЯК ЧАСТИНА СВІТОВОГО КУЛЬТУРНОГО НАДБАННЯ (ЗА МАТЕРІАЛАМИ МЕХП ІН НАН УКРАЇНИ ${ }^{1}$ )
}

\author{
Булгакова-Ситник Л. П. \\ кандидат історичних наук, \\ стариий науковий співробітник \\ Національної академії наук Украӥни, \\ стариий науковий співробітник \\ Музею етнографії та художнього промислу \\ Інституту народознавства національної академї̈ наук Украӥни \\ м. Львів, Україна
}

Музейне колекціонування на території сучасної України започаткувалося у другій половині XIX ст. У Львові, який у той час був одним із головних осередків українського і польського політичного, громадського, релігійного і культурного життя в умовах АвстроУгорської імперії, було засновано кілька музейних інституцій [1, с. 71-98]. Серед них Міський промисловий музей (1874 р. далі МПМ) і Музей Наукового товариства ім. Шевченка (1895р.). 1951 року

1 МЕХП ІН НАН України - Музей етнографії та художнього промислу Інституту народознавства НАН України. 
новостворений Державний музей етнографії та художнього промислу Академії наук УРСР у Львові успадкував збірки Музею художнього промислу ${ }^{2}$ та Етнографічного музею ${ }^{3} .1992$ року Музей етнографії та художнього промислу стає структурним підрозділом Інституту народознавства НАН України (далі МЕХП) [2, с. 22-26]. Нині МЕХП справжня скарбниця пам'яток традиційної культури українців, а також зразків декоративно-прикладного мистецтвах багатьох народів світу.

Основу збірки україністики склали колекції Етнографічного музею, а колекції західноєвропейської та азійської культури надійшли з Музею художнього промислу. Колекції українського традиційного вбрання та вишивки найвагоміші та найрізноманітніші серед об'єктів народної культури українців. Десятки тисяч пам'яток дають повне уявлення про регіональні особливості культури одягання українців та декорування окремих видів вбрання. До унікальних можна віднести чисельні колекції українських виробів середини XIX - початку XX ст.: писанок, дитячих іграшок, народної кераміки, домотканих килимів і хатніх тканин, прикрас, художніх виробів з дерева та металу. Музейні пам'ятки стали основою для багатьох наукових досліджень присвячених українській традиційній культурі та мистецтву [3; 4; 5; 6; 7; 8; 9; 10;11].

Історія формування музейного фонду зарубіжних художніх промислів складна й неоднозначна. Його основу складають колекції окремих музеїв, приватних зібрань, подарунки приватних осіб. Зокрема МПМ, приватних збірок родин Дідушицьких, Лянцкоронських, князів Любомирських, а також інших інституцій - Міської збірки К. Бруніцкого, Державного музею ім. Льва Пінінського, Публічної збірки Б. Ожеховича, Музею єврейського кагалу, Вірменського музею дієцезії, Приватного музею М. Гольдштейна та ін.

Вагоме місце серед інших колекцій музейної збірки належить колекції художнього скла 3 понад 4500 зразків зарубіжного та українського скловиробництва XVI - початку XXI ст. Зібрання має універсальний характер. Це ужитковий посуд, люстри, дзеркала, вітражі тощо. Географічно найчисельніше представлені вироби 3 країн Центральної та Західної Європи - Чехії, Німеччини, Польщі, Франції. Серед збережених пам'яток - вироби, що не мають аналогів у вітчизняних і зарубіжних музеях. Велику цінність становлять унікальний

21939 року відбулася реорганізація Міського промислового музею в Музей художнього промислу Міністерства культури УРСР.

31940 року після ліквідації НТШ на основі етнографічної збірки Культурноісторичного музею було створено Державний етнографічний музей. 
різьблений келих 3 накривкою 3 портретом Августа II (Дрезден, 1730-1731 pp.), сервіз з гербом «Nałęcz» з Гути Кришталевої (XVIII ст.) $[13$, c. 28$]$.

Зібрання промислової кераміки (фарфору, фаянсу, майоліки, кам'яної маси) нараховує більше 10 тисяч експонатів 3 багатьох країн світу: Австрії, Англії, Голландії, Данії, Італії, Іспанії, Китаю, Перу, Росії, Туреччини, Чехії, Угорщини, Японії. Основні групи зібрання - предмети західноєвропейських виробництв XVII - XIX ст. Найчисленніші колекції Мейсенської та Віденської мануфактур. Значне місце у колекції англійської кераміки займають вироби з кам'яної маси, відомі під назвою «Веджвуд». У колекції представлена італійська майоліка з Урбіно, Кастель Дуранте, Костеллі (XVI - XVII ст.), іспано-мавританська кераміка та рідкісна кераміка хабанів (кінця XVII - початку XVIII ст.), голландські вироби з Делфта, страсбурзький фаянс майстерні Ганнонгів (XVIII ст.) та ін.

Колекцію ювелірних виробів складають близько 3 тисяч різноманітних предметів XVI - XX ст. з різних країн Свропи та Азії. Унікальні чисельні колекції табакерок i кишенькових годинників, оздоблених дорогоцінними металами й камінням, жіночі прикраси, віяла.

МЕХП $\epsilon$ власником одного 3 найбільших зібрань сакральних християнських пам'яток в Україні, яке умовно можна розділити на дві великі групи. До першої належать об'єкти, за допомогою яких відбуваються церковно-обрядові дійства, а другу складають ужиткові речі 3 християнською символікою. Найчисленніша в цій колекції представлена текстильна група до якої відносяться кілька сотень богослужебного облачення духовенства - як, грецького, так i латинського обряду [14, с. 520-525]. Колекція цінна не лише з точки зору тематичної приналежності пам'яток, а й тканини з якої пошиті вироби. Здебільшого це шовкові, оксамитові дорогоцінні тканини XVII - XIX ст. 3 відомих західноєвропейських та азійських ткацьких осередків $[14$, c. 523-525]. Крім літургійних тканин у зібранні історичної художньої тканини представлені унікальні колекції шпалер XVII-XVIII ст. італійського, французького, голландського походження; орієнтальних килимів з анатолійських і кавказьких килимарських центрів; світського одягу XVIII - початку XX ст., який доповнюють кашмірські шалі, зразки тканин i мережева XVI-XIX ст. 3 відомих європейських ткацьких осередків. Найбільша не лише в Україні, а й у всій Європі колекція золототканих і шовкових поясів XVIII - середини XIX ст. - неоціненний музейний скарб. 
МЕХП зберігає найбільшу в Україні колекцію пам'яток пов'язаних з єврейською релігійною традицією. Це сакральні предмети, які використовувалися в ритуальних церемоніях у синагогах. Сюди входять тканини, якими прикрашали синагоги (парохети, капорети, меіли), вироби з металу (менори, таси, кетери, дзбани), паперові прикраси (мізрахи), дерев'яні пюпітри (амуди), указки (яди) з дерева, срібла, кістки для читання Тори. Вагому частину колекції складають пам'ятки, що належать до сімейної релігійної традиції юдеїв: амулети (мезуза), підсвічники (ханукії), ємності для пахощів (бсаміми), святковий й ритуальний посуд. Предмети ритуального одягу (атари, брушттухи, ярмулки, пояси, жіночі капори), весільні перстні, ремісничі вироби 3 дерева та тканини.

Осібне місце серед інших зібрань МЕХП посідає збірка графіки. Її вагомою складовою є колекції світового плакату кінця XIX - першої половини XX ст., що репрезентують твори плакатного мистецтва України, Польщі, Австрії, Німеччини, Іспанії, Угорщини, США, Чехії, Румунії, Швейцарії, Росії. Однією 3 найзмістовніших $є$ колекція французького плакату, яку прикрашають твори авторства Анрі де ТулузЛотрека [15]. За якістю представлених пам'яток і за їх кількістю найпомітніша колекція польського плакату з якої можна виокремити тематичну групу стилю ар деко [16]. Порівняно малочисельна, але виразна колекційна група американського рекламного плакату [17]. Справжньою колекційною перлиною чеського плакату є твори Альфонса Мухи [18].

Навіть стислий огляд колекційного розмаїття збірки МЕХП дозволяє скласти уяву про неоціненний культурний спадок від минулих поколінь прийдешнім. Всебічне залучення емпіричного музейного матеріалу дозволить історикам, етнографам розкрити нові аспекти низки малодосліджених проблем етнокультурної історії України. Дасть можливість здійснити або уточнити атрибуцію музейних пам'яток, провести їх порівняння з синхронними іноземними зразками.

\section{Література:}

1. Скрипник Г. А. Етнографічні музеї України. К.: Наукова думка, 1989. $300 \mathrm{c}$.

2. Павлюк С., Чмелик Р. Скарби Музею етнографії та художнього промислу Інституту народознавства НАН України. Львів, 2005. 226 с.

3. Матейко К. І. Український народний одяг. К.: Наукова думка, 1977. 224 c. 
4. Захарчук-Чугай Р.В. Народне декоративне мистецтво Яворівщини. К.: Наукова думка, 1979. 144 с.

5. Горинь Г. Й. Шкіряні промисли західних областей України. К.: Наукова думка, 1986.94 с.

6. Стельмащук Г. Г. Традиційні головні убори українців. К.: Наукова думка, 1993. 237 с.

7. Булгакова-Ситник Л. Подільська народна вишивка (Етнографічний аспект). Львів, 2008. 324

8. Никорак О. Сучасні художні тканини українських Карпат. К.: Наукова думка, 1988. 182 с.

9. Станкевич М. Українські витинанки. К.: Наукова думка, 1986. $123 \mathrm{c}$.

10. Сидорович С. Й. Художня тканина західних областей УРСР. К.: Наукова думка, 1979. $153 \mathrm{c}$.

11. Жолтовський П. М. Художнє лиття на Україні. К.: Наукова думка, 1973. $132 \mathrm{c}$.

12. Петрякова Ф. С. Український художній фарфор (кін. XVIII - поч. ХХ ст.). К.: Наукова думка, 1985. 221 с.

13. Скоропадова Г. Історія формування колекції європейського скла XVI - XIX ст. у Музеї етнографії та художнього промислу. Свропейське скло. Варшава, 2008. С. 19-28

14. Булгакова-Ситник Л. Пам'ятки християнства у Музеї етнографії та художнього промислу Інституту народознавства НАН України. Українська культура: $з$ нових досліджень. Львів, 2007. С. 517-539

15. Сенків М. Анрі де Тулуз-Лотрек та французький плакат кін. XIX поч. XX ст. зі збірки Музею етнографії та художнього промислу IН НАН України. Львів, 2011. 39 с.

16. Серадзька А. Польський плакат Art Deko 3 фондів Музею етнографії та художнього промислу ІН НАН України. Музей Замойських у Козлувці. 2005. 206 с.

17. Сеньків М. Американський плакат кін. XIX - поч. XX ст. зі збірки Музею етнографії та художнього промислу IH НАН України. Львів, 2005. $32 \mathrm{c}$.

18. Сеньків М. Альфонс Муха. Плакати зі збірки Музею етнографії та художнього промислу ІН НАН України. Львів, 2010. 38 с. 